\title{
Evaluation of grazing beef cows receiving supplements with different protein contents
}

\section{Avaliação de vacas de corte em pastejo recebendo suplementos com diferentes teores de proteína}

\author{
Sidnei Antônio Lopes ${ }^{1 *}$; Mário Fonseca Paulino²; Edenio Detmann²; \\ Luciana Navajas Rennóz; Ériton Egídio Lisboa Valente3; Carla Heloísa Avelino Cabral"; \\ Victor Valério de Carvalho ${ }^{5}$; Josilaine Aparecida da Costa Lima; \\ Marcos Rocha Manso ${ }^{5}$; Hugo Colombarolli Bonfá ${ }^{5}$
}

\begin{abstract}
The aim of this study was to evaluate the effects of supplementation with different crude protein contents on the productive performance of grazing beef cows during post-calving. Thirty-six beef cows, with age and average body weight of 5 years and $490 \pm 17.9 \mathrm{~kg}$, respectively, were used. The experimental design was completely randomized. The treatments were: control = cows received only mineral mixture ad libitum; supplemented $=$ cows received $1 \mathrm{~kg} \mathrm{~d}^{-1}$ of supplement containing 80,200 , or $320 \mathrm{~g}$ crude protein $(\mathrm{CP}) \mathrm{kg}^{-1}$. There was no effect $(\mathrm{P} \geq 0.16)$ of supplementation on voluntary intake. A linear effect $(\mathrm{P}<0.02)$ of the $\mathrm{CP}$ content in the supplements was observed among supplemented cows, only for the $\mathrm{CP}$ intake. Supplementation did not affect $(\mathrm{P} \geq 0.20)$ the total digestibility of organic matter, neutral detergent fiber corrected for ash and protein, and CP. Among supplemented cows, a positive linear effect $(\mathrm{P}<0.01)$ of the $\mathrm{CP}$ content in the supplement was observed for the CP digestibility. Intestinal flow of microbial nitrogen compounds and efficiency of synthesis microbial were not affected $(\mathrm{P} \geq 0.18)$ by treatments. Performance, milk yield and composition were not also affected $(\mathrm{P} \geq 0.11)$ by treatments. Supplementation did not affect $(\mathrm{P} \geq 0.52)$ non-esterified fatty acids, urea nitrogen and progesterone serum concentrations. It is concluded that supplementation of grazing beef cows during post-calving does not affect nutritional and productive performance.
\end{abstract}

Key words: Beef cows. Intake. Nellore. Non-esterified fatty acids. Supplementation.

\section{Resumo}

Objetivou-se avaliar os efeitos da suplementação com diferentes teores de proteína sobre o desempenho produtivo de vacas de corte em pastejo durante o pós-parto. Foram utilizadas 36 vacas de corte com idade e peso corporal médio de 5 anos e $490 \pm 17,9 \mathrm{~kg}$, respectivamente. O delineamento experimental foi inteiramente casualizado. Os tratamentos foram: controle $=$ vacas receberam somente mistura mineral

1 Dr. em Zootecnia, Departamento de Zootecnia, Universidade Federal de Viçosa, UFV, Viçosa, MG, Brasil. E-mail: sidneyufv@, hotmail.com

2 Profs., Departamento de Zootecnia, UFV, MG, Brasil.E-mail: mpaulino@ufv.br; detmann@ufv.br; lucianarenno@ufv.br

3 Prof., Departamento de Zootecnia, Universidade Estadual do Oeste do Paraná, UNIOESTE, Marechal Candido Rondon, PR, Brasil. E-mail: eritonvalente@yahoo.com.br

4 Prof ${ }^{\mathrm{a}}$, Departamento de Zootecnia, Universidade Federal do Mato Grosso, UFMT, Cuiabá, MT, Brasil. E-mail: cabralcha@ hotmail.com

5 Discentes do Curso de Pós-Graduação em Zootecnia, Departamento de Zootecnia, UFV, Viçosa, MG, Brasil. E-mail: victorvaleriomg@hotmail.com; josilainelima.zootecnia@yahoo.com.br; marcos.manso@ufv.br; hugo.bonfa@ufv.br

* Author for correspondence 
ad libitum; suplementados $=$ vacas receberam $1 \mathrm{~kg} \mathrm{dia}^{-1}$ de suplemento contendo 80,200 ou $320 \mathrm{~g}$ de proteína bruta $(\mathrm{PB}) \mathrm{kg}^{-1}$. Não houve efeito $(\mathrm{P} \geq 0,16)$ da suplementação sobre consumo voluntario. Entre os animais suplementados, o consumo de proteína aumentou linearmente $(\mathrm{P}<0,02)$ com o teor de $\mathrm{PB}$ no suplemento. A suplementação não afetou $(\mathrm{P} \geq 0,20)$ a digestibilidade total da matéria orgânica, fibra em detergente neutro corrigida para cinza e proteína (FDNcp) e da proteína. Entre os animais suplementados, houve efeito linear positivo $(\mathrm{P}<0,01)$ dos teores de $\mathrm{PB}$ nos suplementos sobre a digestibilidade da $\mathrm{PB}$. $\mathrm{O}$ fluxo intestinal de compostos nitrogenados microbianos e a eficiência de síntese de proteína microbiana não foram afetados $(\mathrm{P} \geq 0,18)$ pelos tratamentos. $\mathrm{O}$ desempenho, produção e a composição do leite não foram afetados $(P \geq 0,11)$ pelos tratamentos. A suplementação não afetou $(P \geq 0,52)$ as concentrações séricas de ácidos graxos esterificados, ureia e progesterona. Conclui-se que a suplementação de vacas de corte em pastejo durante pós-parto não afeta o consumo e o desempenho produtivo.

Palavras-chave: Ácidos graxos não esterificados. Consumo. Nelore. Suplementação. Vacas de corte.

\section{Introduction}

For efficient production of beef cattle on pastures, cows need to yield a calf every 12-13 months. However, the creation phase is normally conducted with low-quality forages and supplementation of beef cows is still an uncommon practice in Brazil.

Nutrition directly influences the fertility of ruminants, as in the supply of specific nutrients necessary for the ovulation process, fertilization, embryo survival and development; and indirectly through the impact on the circulation of hormones and metabolites integral to those processes (ROBINSON et al., 2006).

Poorly-nourished cows with low-body condition scores are inefficient during the following breeding season (CABRAL et al., 2012). According to Peixoto and Osório (2007), protein intake below that which is recommended during the peripartum period negatively affects the productive performance of beef cows.

Strategic supplementation during certain months of the year could contribute to maintaining the body condition of beef cows in the post-calving period and, consequently, enhance productive and reproductive performance.

Therefore, the objective of this study was to evaluate the effects of supplying supplements with different crude protein contents on the productive performance of grazing beef cows during postcalving.

\section{Materials and Methods}

All procedures involving animals were approved by the Institutional Committee of Universidade Federal de Viçosa for animal care and use experimentation, process UFV number 43/2014.

\section{Animals, experimental design and diets}

The experiment was conducted at the Universidade Federal de Viçosa, MG, Brazil, $\left(20^{\circ} 45^{\prime} \mathrm{S}, 42^{\circ} 52^{\prime} \mathrm{W}\right)$, between September and November of 2012, during transition phase between dry and rainy seasons. The experimental area was located in a hilly region, at altitude of $670 \mathrm{~m}$. Over days measurements, the average minimum and maximum temperatures were respectively, $13.6^{\circ} \mathrm{C}$ and $27.8^{\circ} \mathrm{C}$ in September, $16.0^{\circ} \mathrm{C}$ and $29.6^{\circ} \mathrm{C}$ in October, and $18.3^{\circ} \mathrm{C}$ and $26.5^{\circ} \mathrm{C}$ in November. The amounts of rainfall were $46.9 \mathrm{~mm}$ in September, $98.9 \mathrm{~mm}$ in October and $225.3 \mathrm{~mm}$ in November (DEPARTMENT OF AGRICULTURAL ENGINEERING - UFV).

Thirty-six Nellore beef cows, averaging 5 yearsold and $490 \pm 17.9 \mathrm{~kg}$ of body weight (BW), were used. The treatments were distributed randomly to the cows at calving occurrence. The treatments for the cows were: control $=$ cows received only mineral mixture ad libitum; supplemented = cows received $1 \mathrm{~kg}$ of supplement containing 80,200 , or $320 \mathrm{~g}$ of crude protein (CP) $\mathrm{kg}^{-1}$ (Table 1), fed once a day at $11 \mathrm{~h} 00$. 
The evaluations started from the first day post-calving. The period between the first and last calving lasted 25 days, consequently, the experiment lasted 85 days. Before calving, all cows were managed into a 30 -ha paddock with Brachiaria decumbens, where they receiving only mineral mixture ad libitum. After calving, cow-calf pairs were managed into a 40-ha with Brachiaria decumbens, divided in four paddocks of 10-ha each, where there were drinkers and shaded feeders in each paddock and cows received one of the treatments.

Table 1. Supplement composition $\left(\mathrm{g} \mathrm{kg}^{-1}\right)$ as fed.

\begin{tabular}{lccc}
\hline \multirow{2}{*}{ Ingredient } & \multicolumn{3}{c}{ Crude protein content } \\
\cline { 2 - 4 } & 80 & 200 & 320 \\
\hline Ground corn grain & 470 & 305 & 140 \\
Ground sorghum grain & 470 & 305 & 140 \\
Soybean meal & 0 & 330 & 660 \\
Mineral mixture $^{\mathrm{a}}$ & 60 & 60 & 60 \\
\hline
\end{tabular}

a mineral mixture composition dicalcium phosphate $(500.0 \mathrm{~g}$ $\left.\mathrm{kg}^{-1}\right)$, sodium chloride $\left(471,9 \mathrm{~g} \mathrm{~kg}^{-1}\right)$, zinc sulfate $\left(15.0 \mathrm{~g} \mathrm{~kg}^{-1}\right)$, copper sulfate $\left(7.0 \mathrm{~g} \mathrm{~kg}^{-1}\right)$, cobalt sulfate $\left(0.5 \mathrm{~g} \mathrm{~kg}^{-1}\right)$, potassium iodide $\left(0.5 \mathrm{~g} \mathrm{~kg}^{-1}\right)$, sodium selenite $\left(0.1 \mathrm{~g} \mathrm{~kg}^{-1}\right)$, and manganese sulfate $\left(5.0 \mathrm{~g} \mathrm{~kg}^{-1}\right)$.

In order to minimize the possible effects of paddocks on the experimental treatments, animals were rotated among the paddocks every 7 days, so that each group stayed on each paddock for the same period of time.

\section{Experimental procedures and sampling}

For performance evaluation, the cows were weighed on the first, thirtieth, and sixtieth days post-calving (always in the morning at $6 \mathrm{~h} 30$ ), and the body condition score (BCS) of the cows was evaluated by the same four evaluators, using a scale from 1 to 9, as recommended by the NRC (1996).

Forage samples were collected every 28 days, from day 14 of the experiment, to evaluate forage availability. In each paddock, four samples of forage were randomly selected using a metallic square $(0.5 \times 0.5 \mathrm{~m})$, and cut approximately $1 \mathrm{~cm}$ above the ground. Sampling for the qualitative assessment of forage consumed by the animals was obtained every fourteen days by the hand-plucking method. All the samples were dried $\left(60^{\circ} \mathrm{C}\right.$ for 72 hours) and ground in a Wiley mill (model 3, Arthur H. Thomas, Philadelphia, PA) to pass through a 2 $\mathrm{mm}$ screen. After that, half of each ground again to pass through a $1 \mathrm{~mm}$.

To estimate milk yield, cows were milked at days 32 and 62 of the experiment. Cows were separated from their calves at $18 \mathrm{~h} 00$. At $6 \mathrm{~h} 00$ of the following day, cows were injected with $2 \mathrm{~mL}$ oxytocin (10 IU $\mathrm{mL}^{-1}$; Ocitovet $\AA$, Brazil) in the mammary artery and immediately milked. The exact time when each cow was milked was recorded, and the milk produced was proportionally converted into a $24 \mathrm{~h}$ based production. The milk produced was corrected to 4 $\%$ of fat (FCM) according to NRC (2001):

$$
\mathrm{FCM}=0.4 \times \text { milk yield }\left(\mathrm{kg} \mathrm{d}^{-1}\right)+15 \times \text { fat yield }\left(\mathrm{kg} \mathrm{d}^{-1}\right)
$$

Twenty days after the last calving, a nine-day assay was carried out to evaluate voluntary intake and digestibility of the cows. Chromium oxide $\left(\mathrm{Cr}_{2} \mathrm{O}_{3}\right)$, used to estimate fecal excretion, was packaged in paper cartridges in the amount of 20 $\mathrm{g}$ per cow $\mathrm{d}^{-1}$, and was introduced (11h00) into the esophagus via a rubber tube; while titanium dioxide $\left(\mathrm{TiO}_{2}\right)$, used to estimate individual supplement intake, was mixed with the supplement distributed to the cows in an amount equal to $15 \mathrm{~g}$ per animal $\mathrm{d}^{-1}$. The first 6 days were used to stabilize the flow of markers in gastrointestinal tract of the animals, while the last 3 days were used for feces collection at $16 \mathrm{~h} 00$ on day 7 , at $11 \mathrm{~h} 00$ on day 8 , and at $6 \mathrm{~h} 00$ on day 9 , respectively. The fecal samples were collected immediately after animal defecation or directly in the rectum, at the approximate amount of $200 \mathrm{~g}$. Then the samples oven-dried $\left(60^{\circ} \mathrm{C}\right.$ for 72 
hours) and proportionally pooled per animal, then ground in a Wiley mill (model 3, Arthur H. Thomas, Philadelphia, PA) to pass through a $2 \mathrm{~mm}$ screen. After that, half of each ground sample was ground again to pass through a $1 \mathrm{~mm}$ screen. In the fifth day of the digestibility assay, a sample of forage in each paddock was obtained by the hand-plucking method, to estimate voluntary intake and digestibility.

To evaluate the microbial protein production of cows, spot urine samples $(10 \mathrm{~mL})$ were collected from spontaneous micturition 4 hours after supply of supplement in the $9^{\text {th }}$ day of the digestibility assay. Urine samples were diluted in $40 \mathrm{~mL}$ of $\mathrm{H}_{2} \mathrm{SO}_{4}(0.036 \mathrm{~N})$ and frozen at $-20{ }^{\circ} \mathrm{C}$.

Blood samples were collected on the thirtieth and sixtieth days post-calving via jugular vein puncture, using vacuum tubes with separator gel (BD Vacutainer ${ }^{\circledR}$ SST II Advance) and centrifuged at $3000 \times \mathrm{g}$ for 15 minutes and the serum was then frozen at $-20^{\circ} \mathrm{C}$.

\section{Chemical analysis}

Samples of forage, feces, and supplement processed to pass through $1 \mathrm{~mm}$ screen sieve, were analyzed according to the standard analytical procedures of the Brazilian National Institute of Science and Technology in Animal Science (INCTCA) (DETMANN et al., 2012) for dry matter (DM; INCT-CA method G-003/1), ash (INCT-CA method M-001/1), crude protein (CP; INCT-CA method $\mathrm{N}-001 / 1$ ), ether extract (EE; INCT-CA method G-004/1), neutral detergent fiber (NDF; INCTCA method F-002/1), using alpha thermostable amylase without addition of sodium sulfite and corrected for ash and nitrogen compounds (NDIP; INCT-CA method N-004/1). Indigestible neutral detergent fiber (iNDF; INCT-CA method F-009/1) was quantified by in situ incubation procedures with F57 bags (Ankom ${ }^{\circledR}$ ) for 288 hours in samples processed at $2 \mathrm{~mm}$. In addition, fecal samples were evaluated for the contents of chromium (INCT-CA method M-005/1) and titanium (INCT-CA method M-007/1). Milk samples were analyzed with regards as protein, fat, lactose, and total solids content using infrared spectroscopy (Foss MilkoScan FT120, Hillerød, Denmark).

The percentage of potentially digestible DM (DMpd) in the forage samples obtained for evaluation of forage availability was estimated according to Paulino et al. (2008):

$$
D M p d=0.98 X(100-N D F)+(N D F-i N D F)
$$

where: $\mathrm{DMpd}=$ forage content of potentially digestible DM (DM \%); 0.98 = true digestible coefficient of cell content; and NDF and $\mathrm{NDF}=$ forage content of NDF and iNDF, respectively (DM \%).

Fecal excretion was estimated by rationing the quantity of chromic oxide offered and the concentration in feces.
Individual DM intake of supplement (DMS) was estimated by relation of excretion of $\mathrm{TiO}_{2}$ in feces and marker concentration in the supplement.

The voluntary intake of DM from forage (DMF) was estimated using an internal iNDF according to Detmann et al. (2001), using the following equation:

$$
D M F=[(F E \times i N D F f e c e s)-D M S i \times i N D F \text { sup }] \div i N D F f o r a g e
$$

where $\mathrm{FE}=$ fecal excretion $\left(\mathrm{kg} \mathrm{d}^{-1}\right)$, iNDFfeces $=\quad=$ concentration of iNDF in the supplement $\left(\mathrm{kg} \mathrm{kg}^{-}\right.$ concentration of iNDF in the feces $\left.\left(\mathrm{kg} \mathrm{kg}^{-1}\right), \mathrm{DMSi}{ }^{1}\right)$, and iNDF forage = concentration of iNDF in the $=$ dry matter supplement intake $\left(\mathrm{kg} \mathrm{d}^{-1}\right)$, iNDFSup forage $\left(\mathrm{kg} \mathrm{kg}^{-1}\right)$. 
The total DM intake was calculated by the sum of DMF intake and DMS intake.

Samples serum were analyzed for concentrations of progesterone (P4), non-esterified fatty acids (NEFA), and serum urea nitrogen (SUN) by chemiluminescence, enzymatic spectrophotometry, and kinetic fixed time methods, respectively. The analyses were conducted at clinical analyses Laboratory (Viçosalab, Viçosa, MG). Progesterone concentrations higher than $1 \mathrm{ng} \mathrm{ml}^{-1}$ (P4>1 ng ml$\left.{ }^{1}\right)$ were considered indicator of ovarian activity (NOGUEIRA et al., 1993).

In the samples of urine, analyses were carried out for creatinine, uric acid, and urea by colorimetric kinetic, enzymatic colorimetric and kinetic fixed time methods, respectively, using automatic biochemical analyzer (Mindray, BS200E model).

Daily urinary volume was calculated using the relationship between the daily creatinine excretion (CE), taking as reference the equation proposed by Costa e Silva et al. (2012), and its concentration in the spot samples:

$$
\mathrm{CE}\left(\mathrm{g} \mathrm{d}^{-1}\right)=0.0345 \times \mathrm{SBW}^{0.9491}
$$

where: SBW = shrunk body weight

Allantoin was analyzed by the colorimetric method as described by Chen and Gomes (1992). Total excretion of purine derivatives was calculated by the sum of the amounts of allantoin and uric acid excreted in urine.

The purines absorbed were calculated from the excretion of purine derivatives according the equation Barbosa et al. (2011):

$$
A P=\frac{\left(P D-0.301 x B W^{0,75}\right)}{0.80}
$$

where: $\mathrm{AP}=$ absorbed purines $\left(\mathrm{mmol} \mathrm{d}^{-1}\right)$; PD $=$ excretion of purine derivative $\left(\mathrm{mmol} \mathrm{d}^{-1}\right) ; 0.301$ $=$ endogenous excretion of purine derivative in the urine (mmol) per unit of metabolic weight $\left(\mathrm{BW}^{0.75}\right)$; and $0.80=$ recovery of purine absorbed as purine derivative in the urine $\left(\mathrm{mmol} \mathrm{mmol}{ }^{-1}\right)$.

Ruminal synthesis of microbial nitrogen compounds was calculated as a function of AP using the equation described by Barbosa et al. (2011).

$$
N M I C=\frac{(70 \times A P)}{(0.93 \times R \times 1000)}
$$

where: $\mathrm{NMIC}=$ flow of microbial nitrogen compounds $\left(\mathrm{g} \mathrm{d}^{-1}\right) ; 70=\mathrm{N}$ content in purines $(\mathrm{mg} \mathrm{N}$ $\left.\mathrm{mol}^{-1}\right) ; 0.93=$ digestibility of microbial purines and $0.134=\mathrm{N}$ purine: total $\mathrm{N}$ in the bacteria according to Valadares et al. (1999).

\section{Statistical analysis}

The experiment was carried out according to a completely randomized design, including the fixed effects of treatments and using BW of the cows at calving as a covariate. The comparisons among treatments were performed out by a set of orthogonal contrasts which encompassed a comparison between the control treatment and the treatments with supplementation, and the linear and quadratic effects of the content of $\mathrm{CP}$ in supplements. All statistical procedures were performed adopting 0.10 as the critical level of probability for the type I error and the MIXED procedure of the Statistical Analysis System 9.4 (SAS Institute, Inc.).

\section{Results}

The average availability of DM and DMpd during the experiment was $5.3 \mathrm{t} \mathrm{ha}^{-1}$ and $3.1 \mathrm{t} \mathrm{ha}^{-1}$, respectively, which corresponded to the momentary average availability of 203.1 and $119.0 \mathrm{~g} \mathrm{~kg}^{-1} \mathrm{BW}$. Forage sampled by hand-plucking had an average CP content of $72 \mathrm{~g} \mathrm{~kg}^{-1} \mathrm{DM}$ (Table 2).

The milk yield and composition were not affected $(\mathrm{P} \geq 0.11)$ by the treatments (Table 3 ). 
Table 2. Chemical composition of the supplements and forage.

\begin{tabular}{lccccc}
\hline \multirow{2}{*}{ Item } & \multicolumn{3}{c}{ Crude protein content $\left(\mathrm{g} \mathrm{kg}^{-1} \mathrm{DM}\right)$} & \multicolumn{2}{c}{ Brachiaria decumbens } \\
\cline { 2 - 6 } & 80 & 200 & 320 & Forage $^{\mathrm{d}}$ & Forage $^{\mathrm{e}}$ \\
\hline $\mathrm{DM}^{\mathrm{a}}$ & 955 & 952 & 957 & $326 \pm 0.6$ & $348 \pm 0.3$ \\
$\mathrm{OM}^{\mathrm{b}}$ & 939 & 921 & 903 & $921 \pm 0.2$ & $932 \pm 0.4$ \\
$\mathrm{CP}^{\mathrm{b}}$ & 77 & 209 & 329 & $72 \pm 0.8$ & $70 \pm 0.5$ \\
$\mathrm{EE}^{\mathrm{b}}$ & 11 & 13 & 14 & $9 \pm 0.2$ & $8 \pm 0.6$ \\
$\mathrm{NDFap}^{\mathrm{b}}$ & 138 & 150 & 155 & $658 \pm 1.1$ & $698 \pm 0.5$ \\
$\mathrm{NFC}^{\mathrm{b}}$ & 713 & 549 & 405 & $187 \pm 1.1$ & $157 \pm 0.8$ \\
$\mathrm{iNDF}^{\mathrm{b}}$ & 5 & 6 & 6 & $261 \pm 1.4$ & $266 \pm 0.3$ \\
$\mathrm{NDIN}^{\mathrm{c}}$ & 184 & 176 & 137 & $360 \pm 3.3$ & $380 \pm 2.3$ \\
\hline
\end{tabular}

$\mathrm{DM}=$ dry matter; $\mathrm{OM}=$ organic matter; $\mathrm{CP}=$ crude protein; $\mathrm{EE}=$ ether extract; $\mathrm{NDFap}=$ neutral detergent fiber correct for ash and protein; $\mathrm{NFC}=$ non-fiber carbohydrate; $\mathrm{NDF}=$ indigestible neutral detergent fiber; NIDN = insoluble neutral detergent nitrogen. a/ $\mathrm{g} \mathrm{kg}^{-1}$ as fed

b/ $\mathrm{g} \mathrm{kg}^{-1} \mathrm{DM}$

c/ $\mathrm{g} \mathrm{kg}^{-1}$ total nitrogen

$\mathrm{d} /$ Mean \pm standard error of the mean (hand-plucked samples collected throughout study)

`/ Mean \pm standard error of the mean (hand-plucked samples collected during digestibility trial).

Table 3. Least squares means, standard error of the mean (SEM) and significance indicative for milk yield and composition.

\begin{tabular}{|c|c|c|c|c|c|c|c|c|}
\hline \multirow{2}{*}{ Item } & \multirow{2}{*}{ Control } & \multicolumn{3}{|c|}{ Crude protein content $\left(\mathrm{g} \mathrm{kg}^{-1} \mathrm{DM}\right)$} & \multirow{2}{*}{ SEM } & \multicolumn{3}{|c|}{ P value } \\
\hline & & 80 & 200 & 320 & & CONT & $\mathrm{L}$ & Q \\
\hline & $\mathrm{kg} \mathrm{d}^{-1}$ & & & & & & & \\
\hline Milk & 8.55 & 8.94 & 9.21 & 9.26 & 0.87 & 0.370 & 0.296 & 0.720 \\
\hline \multirow[t]{2}{*}{$\mathrm{FCM}^{\mathrm{b}}$} & 8.99 & 8.91 & 9.13 & 9.34 & 0.95 & 0.904 & 0.755 & 0.994 \\
\hline & $\mathrm{g} \mathrm{kg}^{-1}$ & & & & & & & \\
\hline Fat & 43.4 & 39.7 & 39.0 & 34.0 & 0.33 & 0.150 & 0.301 & 0.438 \\
\hline Protein & 29.9 & 29.5 & 3.05 & 3.04 & 0.06 & 0.724 & 0.361 & 0.511 \\
\hline Lactose & 45.0 & 46.3 & 46.0 & 47.4 & 0.08 & 0.109 & 0.346 & 0.383 \\
\hline Total solids & 128.7 & 125.4 & 126.9 & 122.6 & 0.33 & 0.340 & 0.557 & 0.477 \\
\hline
\end{tabular}

a/ $\mathrm{CONT}=$ contrast between supplemented and non-supplemented; $\mathrm{L}$, and $\mathrm{Q}=$ linear and quadratic effects regarding to $\mathrm{CP}$ content in the supplements: 80, 200 and $320 \mathrm{~g} \mathrm{~kg}^{-1}$

b/ FCM $=4 \%$ fat-corrected milk yield.

Overall, there was no effect $(\mathrm{P} \geq 0.16)$ of supplements was observed among supplemented supplementation on voluntary intake (Table 4). A cows strictly for the CP intake (Table 4). linear influence $(\mathrm{P}<0.02)$ of the CP content in the 
Table 4. Least squares means, standard error of the mean (SEM) and significance indicative for voluntary intake.

\begin{tabular}{|c|c|c|c|c|c|c|c|c|}
\hline \multirow{2}{*}{ Item } & \multirow{2}{*}{ Control } & \multicolumn{3}{|c|}{ Crude protein content $\left(\mathrm{g} \mathrm{kg}^{-1} \mathrm{DM}\right)$} & \multirow{2}{*}{ SEM } & \multicolumn{3}{|c|}{ P value $^{\mathrm{a}}$} \\
\hline & & 80 & 200 & 320 & & CONT & $\mathrm{L}$ & Q \\
\hline & $\mathrm{kg} \mathrm{d}^{-1}$ & & & & & & & \\
\hline $\mathrm{DM}$ & 12.01 & 11.27 & 12.00 & 12.23 & 0.84 & 0.860 & 0.431 & 0.812 \\
\hline DMF & 12.01 & 10.43 & 11.10 & 11.42 & 0.77 & 0.260 & 0.373 & 0.860 \\
\hline $\mathrm{OM}$ & 11.19 & 10.52 & 11.18 & 11.34 & 0.78 & 0.852 & 0.445 & 0.813 \\
\hline $\mathrm{CP}$ & 0.83 & 0.79 & 0.96 & 1.06 & 0.07 & 0.812 & 0.012 & 0.688 \\
\hline NDFap & 8.20 & 7.48 & 7.89 & 8.10 & 0.55 & 0.359 & 0.375 & 0.845 \\
\hline iNDF & 3.20 & 2.78 & 2.96 & 3.05 & 0.20 & 0.269 & 0.372 & 0.859 \\
\hline DOM & 6.31 & 5.85 & 6.23 & 6.17 & 0.44 & 0.653 & 0.613 & 0.687 \\
\hline \multirow[t]{2}{*}{ DNDF } & 5.09 & 4.40 & 4.70 & 4.78 & 0.32 & 0.161 & 0.403 & 0.804 \\
\hline & $\mathrm{g} \mathrm{kg}^{-1} \mathrm{BW}$ & & & & & & & \\
\hline $\mathrm{DM}$ & 24.62 & 24.29 & 24.98 & 24.94 & 1.43 & 0.945 & 0.749 & 0.836 \\
\hline DMF & 24.62 & 22.35 & 23.36 & 23.84 & 1.33 & 0.596 & 0.437 & 0.871 \\
\hline $\mathrm{OM}$ & 22.63 & 22.45 & 23.37 & 23.64 & 1.34 & 0.739 & 0.532 & 0.842 \\
\hline NDFap & 16.81 & 16.14 & 16.45 & 16.70 & 0.94 & 0.724 & 0.675 & 0.979 \\
\hline
\end{tabular}

$\mathrm{DM}=$ dry matter, $\mathrm{DMF}=$ forage dry matter, $\mathrm{OM}=$ organic matter, $\mathrm{CP}=$ crude protein, NDFap = neutral detergent fiber corrected for ash and protein, $\mathrm{iNDF}=$ indigestible neutral detergent fiber, $\mathrm{DOM}=$ digestible organic matter, DNDF $=$ digestible neutral detergent fiber

a/ CONT = contrast between supplemented and non-supplemented; $\mathrm{L}$ and $\mathrm{Q}=$ linear and quadratic effects regarding to $\mathrm{CP}$ content in the supplements: 80,200 and $320 \mathrm{~g} \mathrm{~kg}^{-1}$.

The average $\mathrm{CP}$ contents in the diet, calculated from the ratio of CP intake and total DM intake, were 69 , 70,80 , and $82 \mathrm{~g} \mathrm{~kg}^{-1}$ for the control, and supplements with 80, 200, and $320 \mathrm{~g} \mathrm{CP} \mathrm{kg}^{-1} \mathrm{DM}$, respectively.

Supplementation did not affect $(\mathrm{P} \geq 0.20)$ the total digestibility of OM, NDFap, and CP (Table 5).

Table 5. Least squares means, standard error of the mean (SEM) and significance indicative for nutrient digestibility and flow of microbial nitrogen compounds.

\begin{tabular}{|c|c|c|c|c|c|c|c|c|}
\hline \multirow{2}{*}{ Item } & \multirow{2}{*}{ Control } & \multicolumn{3}{|c|}{ Crude protein content $\left(\mathrm{g} \mathrm{kg}^{-1} \mathrm{DM}\right)$} & \multirow{2}{*}{ SEM } & \multicolumn{3}{|c|}{$\mathrm{P}$ value ${ }^{\mathrm{a}}$} \\
\hline & & 80 & 200 & 320 & & CONT & $\mathrm{L}$ & Q \\
\hline $\mathrm{OM}$ & 55.71 & 55.21 & 55.98 & 55.05 & 0.54 & 0.647 & 0.840 & 0.211 \\
\hline $\mathrm{CP}$ & 49.36 & 45.32 & 48.27 & 50.26 & 1.00 & 0.236 & 0.002 & 0.702 \\
\hline NDFap & 61.05 & 60.08 & 60.05 & 60.01 & 0.66 & 0.205 & 0.951 & 0.993 \\
\hline DOM & 525.17 & 518.91 & 519.65 & 504.37 & 5.44 & 0.072 & 0.051 & 0.205 \\
\hline NMIC & 127.36 & 111.65 & 115.30 & 103.06 & 10.51 & 0.181 & 0.577 & 0.543 \\
\hline NMIC/IN & 0.95 & 0.88 & 0.75 & 0.65 & 0.06 & 0.097 & 0.003 & 0.105 \\
\hline EMS & 122.10 & 108.10 & 119.47 & 107.24 & 8.91 & 0.311 & 0.945 & 0.263 \\
\hline
\end{tabular}

$\mathrm{OM}=$ organic matter, $\mathrm{CP}=$ crude protein, $\mathrm{NDFap}=$ neutral detergent fiber corrected for ash and protein, DOM = digestible organic matter $\left(\mathrm{g} \mathrm{kg}^{-1} \mathrm{DM}\right), \mathrm{NMIC}=$ intestinal flow of microbial nitrogen compounds $\left(\mathrm{g} \mathrm{d}^{-1}\right), \mathrm{NMIC} \mathrm{NI}^{-1}=$ intestinal flow of microbial nitrogen compounds $\left(\mathrm{g} \mathrm{g}^{-1}\right.$ ingested $\left.\mathrm{N}\right), \mathrm{EMS}=$ efficiency of microbial protein synthesis ( $\mathrm{g}$ microbial CP synthesis $\mathrm{kg}^{-1} \mathrm{DOM}$ intake) a/ CONT = contrast between supplemented and non-supplemented; L and Q = linear and quadratic effects regarding to CP content in the supplements: 80,200 and $320 \mathrm{~g} \mathrm{~kg}^{-1}$. 
However, among the supplemented cows, a positive linear effect $(\mathrm{P}<0.01)$ of the $\mathrm{CP}$ content in the supplement was observed for the $\mathrm{CP}$ digestibility (Table 5).

The efficiency of microbial protein synthesis (EMS) and NMIC were not affected $(\mathrm{P} \geq 0.18)$ by the treatments. Nevertheless, NMIC, in relation to nitrogen intake (NMIC $\mathrm{NI}^{-1}$ ), was lower in supplemented animals versus control animals. Among supplemented cows, a negative linear effect
$(\mathrm{P}<0.01)$ of the $\mathrm{CP}$ content in the supplements was found for $\mathrm{NMIC} \mathrm{NI}^{-1}$ (Table 5).

There was no $(\mathrm{P} \geq 0.14)$ effect of treatments on performance (Table 6). In addition, supplementation did not affect $(\mathrm{P} \geq 0.52)$ NEFA, SUN and progesterone serum concentrations (Table 7). However, among supplemented cows, a positive linear effect $(\mathrm{P}<0.03)$ of the $\mathrm{CP}$ content of the supplements was seen for SUN concentrations at 30 days post-calving (Table 7).

Table 6. Least squares means, standard error of the mean (SEM) and significance indicative for performance.

\begin{tabular}{|c|c|c|c|c|c|c|c|c|}
\hline \multirow{2}{*}{ Item } & \multirow{2}{*}{ Control } & \multicolumn{3}{|c|}{ Crude protein content $\left(\mathrm{g} \mathrm{kg}^{-1} \mathrm{DM}\right)$} & \multirow{2}{*}{ SEM } & \multicolumn{3}{|c|}{ P value ${ }^{a}$} \\
\hline & & 80 & 200 & 320 & & CONT & $\mathrm{L}$ & Q \\
\hline BW3 & 492.80 & 490.65 & 489.58 & 496.48 & 5.63 & 0.931 & 0.471 & 0.568 \\
\hline BW6 & 469.29 & 476.49 & 477.06 & 476.04 & 5.88 & 0.295 & 0.958 & 0.913 \\
\hline $\mathrm{BCS} 3$ & 4.63 & 4.83 & 4.94 & 4.90 & 0.17 & 0.197 & 0.771 & 0.706 \\
\hline BCS6 & 4.25 & 4.57 & 4.51 & 4.60 & 0.17 & 0.145 & 0.934 & 0.716 \\
\hline
\end{tabular}

BW3, BW6 = body weight in $\mathrm{kg}$; BCS3, BCS6 = body condition score 30 and 60 days post-calving

a/ CONT = contrast between supplemented and non-supplemented; L and Q = linear and quadratic effects regarding to CP content in the supplements: 80,200 and $320 \mathrm{~g} \mathrm{~kg}^{-1}$.

Table 7. Least squares means, standard error of the mean (SEM) and significance indicative for metabolites.

\begin{tabular}{|c|c|c|c|c|c|c|c|c|}
\hline \multirow{2}{*}{ Item } & \multirow{2}{*}{ Control } & \multicolumn{3}{|c|}{ Crude protein content $\left(\mathrm{g} \mathrm{kg}^{-1} \mathrm{DM}\right)$} & \multirow{2}{*}{ SEM } & \multicolumn{3}{|c|}{ P value ${ }^{a}$} \\
\hline & & 80 & 200 & 320 & & CONT & $\mathrm{L}$ & Q \\
\hline NEFA3 & 0.57 & 0.61 & 0.55 & 0.57 & 0.08 & 0.929 & 0.730 & 0.651 \\
\hline NEFA6 & 0.44 & 0.52 & 0.43 & 0.51 & 0.06 & 0.526 & 0.963 & 0.264 \\
\hline SUN3 & 8.49 & 8.28 & 8.73 & 10.04 & 0.51 & 0.383 & 0.021 & 0.500 \\
\hline SUN6 & 13.58 & 12.47 & 12.58 & 15.25 & 1.33 & 0.920 & 0.182 & 0.451 \\
\hline $\mathrm{P} 4 / 3$ & 0.30 & 0.33 & 0.31 & 0.32 & 0.04 & 0.613 & 0.905 & 0.762 \\
\hline $\mathrm{P} 4 / 6$ & 0.25 & 0.24 & 0.32 & 0.25 & 0.05 & 0.915 & 0.595 & 0.128 \\
\hline
\end{tabular}

NEFA $=$ Non esterified fatty acids $\left(\mathrm{mmol} \mathrm{L}^{-1}\right), \mathrm{SUN}=$ serum urea nitrogen $\left(\mathrm{mg} \mathrm{dL}^{-1}\right), \mathrm{P} 4=$ Progesterone $\left(\mathrm{ng} \mathrm{mL}^{-1}\right) 30$ and 60 days post-calving

a CONT = contrast between supplemented and non-supplemented; L and Q = linear and quadratic effects regarding to CP content in the supplements: 80,200 and $320 \mathrm{~g} \mathrm{~kg}^{-1}$.

\section{Discussion}

The forage mass available was not a limiting factor of feed intake in this study. According to Paulino et al. (2008), the interpretation of forage available for grazing as a baseline nutritional resource should be conducted from the perspective of the fraction potentially convertible into animal product, which can be achieved by applying the concept of DMpd, it integrates the quantity and quality regardless of season. The average mass of DMpd $\left(119 \mathrm{~g} \mathrm{~kg}^{-1} \mathrm{BW}\right)$ 
was higher than that recommended by Paulino et al. (2004), specifically from 40 to $50 \mathrm{~g} \mathrm{~kg}^{-1} \mathrm{BW}$ for satisfactory performance. Thus, the availability of forage could be deemed non-restrictive, providing to animals the possibility of highly selective grazing and choosing the best-quality forage parts.

On the other hand, if there is a minimum quantity of forage mass to supply animal demand, canopy structure and nutritive value are more important than forage mass for pasture intake (VALENTE et al., 2013). In tropical pastures, protein is the major limiting factor for production. The average $\mathrm{CP}$ content of forage during the current experiment was $72 \mathrm{~g} \mathrm{CP} \mathrm{kg}^{-1} \mathrm{DM}$; in addition, approximately $360 \mathrm{~g} \mathrm{~kg}^{-1} \mathrm{CP}$ was associated with fibre, being slowly available to ruminal microorganisms (Table 2). According to observations obtained in tropical conditions, additional supply of nitrogen compounds to animals consuming low-quality forage would favor fibrolytic bacteria growth, increasing ruminal NDF degradation, voluntary forage intake and energy extraction from fibrous carbohydrates (PAULINO et al., 2008; DETMANN et al., 2010).

However, positive effects on voluntary intake (Table 4) and fiber digestibility (Table 5) were not observed in this study. The absence of an effect on digestible neutral detergent fiber (DNDF) intake indicates that no change was caused by supplementation or by CP levels on forage intake and digestibility. According to Detmann et al. (2014a), positive responses on fiber degradation have been observed with increased dietary $\mathrm{CP}$ levels for concentrations close to $100 \mathrm{~g} \mathrm{~kg}^{-1} \mathrm{DM}$, and, in addition, the voluntary intake of forage has been stimulated with the establishment of concentrations close to $145 \mathrm{~g} \mathrm{~kg}^{-1}$ DM (DETMANN et al., 2014b). In this study, there was a notable difference in protein intake between supplemented and control cows (Table 4). Although it has been observed a linear increase in protein intake among supplemented animals, dietary CP content increased slightly, remaining below what was suggested by the authors cited earlier, resulting in deficiency of nitrogen compounds for synthesis of microbial enzymes responsible for the degradation of fibrous forage compounds (DETMANN et al., 2009), as result, the absence of changes in digestion and forage intake.

The absence of an effect on voluntary intake reflected on animal performance. Thus, BW did not differ among treatments. In contrast, other studies aiming to evaluate supplementation of beef cows during post-calving in the tropics found improved weight in supplemented animals (RUAS et al., 2000; GODOY et al., 2004). However, Oliveira et al. (2006) highlighted that the evaluation of BCS is more efficient than BW because it takes into account the accumulation of body reserves, which the female has to mobilize during the suckling period. Moreover, two animals can be marked by differences in BW and have similar BCS. Nevertheless, there was no effect of supplementation or of the CP content of the supplements on BCS. More specifically, it was observed that the BCS of the cows was lower than the minimum BCS at parturition (5.0) recommended by the NRC (2000) so that females will have a good reproductive performance in the next breeding season.

Overall, the effects of supplementation on the digestibility coefficients were focused on increasing the $\mathrm{CP}$ digestibility with the elevation of $\mathrm{CP}$ contents in the supplements (Table 5), possibly the result of the lower proportion of metabolic fecal fraction in relation to ingested nutrients (BARROS et al., 2011).

There was no effect of supplementation or of the CP content of the supplements, on NMIC and EMS (Table 5). The absence effect on NMIC has also been observed in other studies assessing beef cattle grazing in tropical conditions (CABRAL et al., 2012; BARROS et al., 2014). This behaviour could be attributed to the fact that in situations where there is a deficiency of nitrogen compounds 
in diet, there would be a net gain of nitrogen to rumen through a recycling system to support the rumen microbial growth that is of first order demand (DETMANN et al., 2014b). However, NMIC NI ${ }^{-1}$ was affected by supplementation and by $\mathrm{CP}$ contents of the supplements. Estimates of NMIC $\mathrm{NI}^{-1}$ higher than one indicate that intestinal flow of microbial nitrogen is higher than ingested nitrogen (DETMANN et al., 2010). In these cases, there will be greater reliance on recycling events to provide an adequate supply of $\mathrm{N}$ in the rumen (DETMANN et al., 2014b). In this study, it may be observed that the average estimates were close to one, in the control animals, and became lower when supplemental CP was provided. This observation again suggests the occurrence of a protein deficit in the animals' diet.

During early lactation, the partitioning mechanisms of nutrients prioritize milk yield over other functions; thus, increasing feed levels by supplementation during post-calving could improve milk yield. However, there was no effect of supplementation or of the $\mathrm{CP}$ content of the supplements on milk yield. Similar results were reported by Ruas et al. (2000) that supplied 1 or $2 \mathrm{~kg}$ of supplement for Nellore cows during postcalving. The absence of effect on milk yield could be attributed, at least in part, to an increased mobilization of body reserves by cows without supplementation. However, the lack of variation in BCS and serum concentration NEFA among supplemented and control cows does not support such an argument. Hence, the absence of answer on total intake (Table 4) as a function of supplementation seems more plausible to explain this.

In post-calving conditions, nutritional requirements of beef cows increase above that which pastures can normally provide, and cows usually enter into a state of negative energy balance (NEB). In this situation, there is fat mobilization and a subsequent increase in NEFA serum concentrations (SARTORI and GUARDIEIRO, 2010). The serum levels of NEFA are quite significant for evaluating the energy state in ruminants, responding quickly to changing feed intake (PEIXOTO et al., 2007). Therefore, by adding supplements to the animals' diet, we would expect higher intake and an improved energy status of the animal, which could be reflected in decreasing serum concentrations of NEFA. However, serum concentrations of NEFA did not differ between treatments (Table 7). Similar results were reported by Mulliniks et al. (2013), in their work with beef cows grazing on native ranges during post-calving.

Overall, there is an absence of studies with Nellore cows in tropical conditions that evaluated the concentrations of blood metabolites, and this hindered a more accurate interpretation of the results. Thus, few studies indicate what threshold of serum NEFA would be considered where there is a high lipid mobilization in beef cows. According to Oetzel (2004), values greater than $0.40 \mathrm{mmol}$ $\mathrm{L}^{-1}$ already suggests problems concerning energy balance. The values of NEFA serum (Table 7) point toward the cows mobilizing body reserves to counterbalance nutritional deficit. Thus, as previously discussed, supplementation failed to increase energy intake of the animals and reduce the NEB.

These observations taken together may justify, at the least in parts, the absence of return to ovarian activity, as evidenced by the low concentration of P4 for all treatments (Table 7). Overall, the results suggest that supplementation was not enough to minimize negative energy balance and induce reproductive response. According to Santos et al. (2009), calved cows are more likely to engage in reconception when presenting weight gain or weight maintenance during the critical period of reproduction.

\section{Conclusions}

It is concluded that supplementation of grazing beef cows during post-calving does not affect nutritional and productive performance. 


\section{Acknowledgements}

The authors wish to thank the Fundação de Amparo à Pesquisa de Minas Gerais (FAPEMIG), Coordenação de Aperfeiçoamento de Pessoal de Nível Superior (CAPES) and INCT Ciência Animal for financial support.

\section{References}

BARBOSA, A. M.; VALADARES, R. F. D.; VALADARES FILHO, S. C.; PINA, D. S.; DETMANN, E.; LEÃO, M. I. Endogenous fraction and urinary recovery of purine derivatives obtained by different methods in Nellore cattle. Journal of Animal Science, Champaign, v. 89, n. 2, p. 510-519, 2011.

BARROS, L. V.; PAULINO, M. F.; MORAES, E. H. B. K.; DETMANN, E.; ALMEIDA, D. M.; MARTINS, L. S.; SILVA, A. G.; LOPES, S. A.; MÁRQUEZ, D. E. C.; CARDENAS, J. E. G. Productive and nutritional performance of beef heifers supplemented in grazing during the dry season and/or transition phase between the rainy and dry seasons. Semina: Ciências Agrárias, Londrina, v. 35, n. 4, p. 2655-2672, 2014.

BARROS, L. V.; PAULINO, M. F.; VALADARES FILHO, S. C.; DETMANN, E.; SILVA, F. G.; VALENTE, E. E. L.; LOPES, S. A.; MARTINS, L. S. Replacement of soybean meal by cottonseed meal $38 \%$ in multiple supplements for grazing beef heifers. Revista Brasileira de Zootecnia, Viçosa, MG, v. 40, n. 4, p. 852-859, 2011.

CABRAL, C. H. A.; PAULINO, M. F.; PAULA, N. F.; VALADARES, R. F. D.; ARAÚJO, F. L. Levels of supplementation for grazing pregnant beef cows during the dry season. Revista Brasileira de Zootecnia, Viçosa, MG, v. 41, n. 12, p. 2441-2449, 2012.

CHEN, X. B.; GOMES, M. J. Estimation of microbial protein supply to sheep and cattle basid on urinary excretion of purine derivatives: an overview of the technical details. International Feed Resources Unit, Rowett Research Institute. Aberdeen: Ed. Buchsburnd, 1992. 21 p. (Ocasional publication).

COSTA E SILVA, L. F.; VALADARES FILHO, S. C.; CHIZOTTI, M. L.; ROTTA, P. P.; PRADOS, L. F.; DINIZ, R. F.; ZANETTI, D.; BRAGA, J. M. S. Creatinine excretion and relationship with body weight of Nellore cattle. Revista Brasileira de Zootecnia, Viçosa, MG, v. 41, n. 3, p. 807-810, 2012.
DETMANN, E.; PAULINO, M. F.; MONTOVANI, H. C.; VALADARES FILHO, S. C.; SAMPAIO, C. B.; SOUZA, M. A.; LAZARINI, I.; DETMANN, K. S. C. Parameterization of ruminal fibre degradation in lowquality tropical forage using Michaelis-Menten kinetics. Livestock Science, Amsterdam, v. 126, n. 1-3, p. 136-146, 2009.

DETMANN, E.; PAULINO, M. F.; VALADARES FILHO, S. C. Optimizing the use of basal forage resources. In: INTERNATIONAL SYMPOSIUM ON BEEF CATTLE PRODUCTION, 3., 2010, Viçosa, MG. Proceedings... Viçosa, MG: UFV, 2010. p. 191-240.

DETMANN, E.; PAULINO, M. F.; ZERVOUDAKIS, J. T.; VALADARES FILHO, S. C.; EUCLIDES, R. F.; LANA, R. P.; QUEIRÓZ, D. S. Chromium and internal markers to estimate the intake of crossbred steers, supplemented steers on pasture. Revista Brasileira de Zootecnia, Viçosa, MG, v. 30, n. 5, p. 1600-1609, 2001.

DETMANN, E.; SOUZA, M. A.; VALADARES FILHO, S. C.; QUEIROZ, A. C.; BERCHIELLI, T. T.; SALIBA, E. O. S.; CABRAL, L. S.; PINA, D. S.; LADEIRA, M. M.; AZEVEDO, J. A. G. Métodos para análise de alimentos. Visconde do Rio Branco: Instituto Nacional de Ciência e Tecnologia de Ciência Animal-INCT, Suprema, 2012. 214 p.

DETMANN, E.; VALADARES FILHO, S. C.; PAULINO, M. F.; HUHTANEN, P. Nutritional aspects applied to grazing cattle in tropics: a review based on Brazilian results. Semina: Ciências Agrárias, Londrina, v. 35, n. 4, p. 2829-2854, 2014a.

DETMANN, E.; VALENTE, E. E. L.; BATISTA, E. D.; HUHTANEN, P. An evaluation of performance and efficiency of nitrogen utilization in cattle feed tropical grass pastures with supplementation. Livestock Science, Amsterdam, v. 162, n. 10, p. 141-153, 2014 b.

GODOY, M. M.; ALVES, J. B.; MONTEIRO, A. L. G.; VALÉRIO FILHO, W. V. Reproductive parameters and Metabolic of Breed Cows Guzerá supplemented before and after calving. Revista Brasileira de Zootecnia, Viçosa, MG, v. 33, n. 1, p. 103-11, 2004.

MULLINIKS, J. T.; KEMP, M. E.; ENDECOT, R. L.; COX, S. H.; ROBERTS, A. J.; WATERMAN, R. C.; GEARY, T. W.; SCHOLLJEGERDES, E. J.; PETERSEN, M. K. Does $\beta$-hydroxybutyrate concentration influence conception date in young postpartum range beef cows? Journal of Animal Science, Champaign, v. 91, n. 1, p. 2902-2909, 2013.

NATIONAL RESEARCH COUNCIL - NRC. Nutrients requirements of beef cattle. $7^{\text {th }}$ ed. Washington: National Academy Press, 1996. 242 p. 
Nutrient requeriments of beef cattle. $7^{\text {th }}$ ed. Washington: National Academy Press, 2000. 248 p.

of Science, 2001. 381 p. $.7^{\text {th }}$ ed. Washington: National Academy

NOGUEIRA, L. A. G.; PINHEIRO, L. E. L.; NORTE, A. L.; ANDRADE, V. J. Uterine involution and return to ovarian cyclic activity in cows Bos taurus indicus. Revista Brasileira de Reprodução Animal, Belo Horizonte, v. 17, n. 1-2, p. 49-56, 1993.

OETZEL, G. R. Monitoring and testing dairy herds for metabolic diseases. Veterinary Clinics of North America. Food Animal Practice, Philadelphia. v. 20, n. 3, p. 651 -674, 2004.

OLIVEIRA, R. L.; BARBOSA, M. A. A. F.; LADEIRA, M. M.; SILVA, M. M. P.; ZIVIANI, A. C.; BAGALDO, A. R. Nutrition and management of beef cattle during the growing period. Revista Brasileira de Saúde e Produção Animal, Salvador, v. 7, n. 1, p. 57-86, 2006.

PAULINO, M. F.; DETMANN, E.; VALADARES FILHO, S. C. Functional production of cattle in the tropics. In: INTERNATIONAL SYMPOSIUM ON BEEF CATTLE PRODUCTION, 2., 2008, Viçosa, MG. Proceedings... Viçosa, MG: UFV, 2008. p. 275-305.

PAULINO, M. F.; FIGUEIREDO, D. M.; MORAES, E. H. B. K.; PORTO, M. O.; SALES, M. F. L.; ACEDO, T. S.; VILLELA, S. D. J.; VALADARES FILHO, S. C. Cattle supplementation in pasture: A systemic view. In: SYMPOSIUM ON BEEF CATTLE PRODUCTION, 4. , 2004, Viçosa, MG. Proceedings... Viçosa, MG: UFV, 2004. p. 93-139.

PEIXOTO, L.A. O.; OSÓRIO, M. T. M. Protein metabolic profile and energy in evaluating the reproductive performance in ruminants. Revista Brasileira de Agrociência, Pelotas, v. 13, n. 3, p. 299-304, 2007.
ROBINSON, J. J.; ASHWORTH, C. J.; ROOKE, J. A.; MITCHELL, L. M.; MCEVOY, T. G. Nutrition and fertility in ruminant livestock. Animal Feed Science Technology, Bucksburn, Aberdeen, v. 126, n. 1, p. 256276, 2006.

RUAS, J. R. M.; TORRES, C. A. A.; VALADARES FILHO, S. C.; PEREIRA, J. C.; BORGES, L. E.; NETO, A. M. Effect of protein supplementation at pasture on forage intake, weight gain and body condition, in Nellore cows. Revista Brasileira de Zootecnia, Viçosa, MG, v. 29, n. 3, p. 930-934, 2000.

SANTOS, S. A.; ABREU, U. G. P.; SOUZA, G. S.; CATTO, J. B. Body condition, weight variation and reproductive performance of beef cows in native pasture in the Pantanal. Revista Brasileira de Zootecnia. Viçosa, MG, v. 38, n. 2, p. 354-360, 2009.

SARTORI, R.; GUARDIEIRO, M. M. Nutritional factors associated with reproduction of female bovine. Revista Brasileira de Zootecnia, Viçosa, MG, v. 39, p. 422-432, 2010. Supplement Special.

VALADARES, R. F. D.; BRODERICK, G. A.; VALADARES FILHO, S. C.; CLAYTON, M. K. Effect of replacing alfalfa silage with high moisture corn on ruminal protein synthesis estimated from excretion of total purine derivatives. Journal Dairy Science, Madison, v. 82, n. 11, p. 2686-2696, 1999.

VALENTE, E. E. L.; PAULINO, M. F.; DETMANN, E.; VALADARES FILHO, S. C.; LOPES, S. A. Performance of young bulls supplemented with different relation of protein and carbohydrate from suckling phase until slaughter in tropical pasture Ratios. Journal of Animal \&Plant Sciences, Lahore, v. 18, n. 2, p. 27112722, 2013. 